\title{
In vitro availability of iron and zinc: effects of the type, concentration and fractions of digestion products of the protein
}

\author{
BY FRANCISCA PÉREZ-LLAMAS ${ }^{1 *}$, \\ MECHTELDIS G. E. DIEPENMAAT-WOLTERS ${ }^{2}$ \\ AND SALVADOR ZAMORA ${ }^{1}$ \\ ${ }^{1}$ Department of Physiology and Pharmacology, Faculty of Biology, University of Murcia, \\ 30100 Murcia, Spain \\ ${ }^{2}$ TNO Nutrition and Food Research, PO Box 360, 3700 AJ Zeist, The Netherlands
}

(Received 11 September 1995 - Revised 2 February 1996-Accepted 20 February 1996)

\begin{abstract}
An in vitro dialysis method was employed to determine the effect on the $\mathrm{Fe}$ and $\mathrm{Zn}$ absorption of the type (beef, pork and soyabean) and the amount $(10$ and $30 \mathrm{~g} / \mathrm{kg}$ ) of protein present. In addition, the effects of low- and high-molecular-weight (LMW and HMW respectively) digestion products were investigated. After in vitro digestion and dialysis a lower percentage of $\mathrm{N}, \mathrm{Fe}$ and $\mathrm{Zn}$ was found in the LMW fractions from beef, pork and soyabean proteins when the protein level was increased from 10 to $30 \mathrm{~g} / \mathrm{kg}$; the higher level of protein being associated with a lower percentage of hydrolysed protein. The highest percentage levels of intrinsic Fe were always found in the HMW fractions, independent of the type and the level of proteins studied, while in the case of $\mathrm{Zn}$, both HMW and LMW fractions gave similar values. An interaction was found between inorganic $\mathrm{Zn}$ and non-haem-Fe. The addition of inorganic $\mathrm{Zn}$ $(10 \mu \mathrm{g} / \mathrm{ml})$ caused a significant decrease in the in vitro availability of Fe from soyabean protein, while it did not affect the dialysability of intrinsic Fe from beef and pork proteins. Our results showed that the type and the level of the protein had a positive effect on the dialysability of extrinsic Fe. We postulate that the effect of a protein on the absorption of extrinsic Fe could be accounted for by free amino acids and/or small peptides released during the digestion process and also by the undigested or partiallydigested HMW fractions of hydrolysed proteins which could play a fundamental role in the availability of this essential element.
\end{abstract}

Iron: In vitro availability: Zinc: Protein digestion

The nutritional value of a diet in terms of macrominerals and trace minerals is dependent on much more than their respective contents in the diet. Mineral imbalances can be attributed not only to a deficient intake, but also to the amount of mineral that is bioavailable for physiological processes in the organism. It is well known that many of the interactions between food constituents can result in changes in the bioavailability of nutrients. Several dietary factors have been implicated in changes in the absorption of some trace minerals, for example Fe, $\mathrm{Zn}, \mathrm{Cu}$ and Mn (Rosenberg \& Solomons, 1982; Solomons, 1982; Mills, 1985; Hallberg, 1987; Sandström, 1988; Churella \& Vivian, 1989; Wapnir \& Devas, 1995). One of the factors which appears to play an important role in $\mathrm{Fe}$ and $\mathrm{Zn}$ absorption is the amount and type of protein in the diet (Cossack \& Prasad, 1983; Snedeker \& Greger, 1983; Van Dokkum et al. 1986; Greger, 1989; Wapnir, 1989).

There have been a number of reports showing that animal tissues in the diet can increase the bioavailability of dietary $\mathrm{Fe}$; this has been attributed to their protein properties (Layrisse et al. 1984; Berner \& Miller, 1985; Politz \& Clydesdale, 1988; Slatkavitz \&

* To whom correspondence should be addressed (telephone 3468 307100; fax 3468 363963). 
Clydesdale, 1988; Gordon \& Godber, 1989). The increasing rate of consumption of soyabean-based foods in human diets has caused some observers to express concern about a possible unfavourable effect on $\mathrm{Fe}$ and $\mathrm{Zn}$ bioavailability. Experiments conducted using different animals have shown a reduced absorption of Fe and $\mathrm{Zn}$ in presence of soyabean products (Forbes et al. 1979; Cook et al. 1981; Thompson \& Erdman, 1984). However, other studies, which have been carried out on human subjects, have given conflicting results (Greger et al. 1978; Van Stratum \& Rudrum, 1979; Bodwell, 1983; Cossack \& Prasad, 1983; Gillooly et al. 1984).

In addition to the influence of food components, there is also the mutual influence of minerals on their individual bioavailabilities. Every year, more examples are published that demonstrate the biological antagonism between minerals. Competitive interactions between $\mathrm{Fe}$ and $\mathrm{Zn}$ have been revealed by a number of investigations (Solomons \& Jacob, 1981; Meadows et al. 1983; Valberg et al. 1984; Fairweather-Tait \& Southon, 1989).

Different types of in vitro methods have been developed for the estimation of the absorption of macrominerals and trace minerals (Narasinga Rao \& Prabhavathi, 1978; Miller et al. 1981; Diepenmaat-Wolters, 1992). In vitro digestion of protein-containing meals and subsequent analysis of soluble or dialysed Fe and $\mathrm{Zn}$ has been shown to have a good correlation with in vivo determinations of $\mathrm{Fe}$ and $\mathrm{Zn}$ absorption (Schricker et al. 1982; Kane \& Miller, 1984; Hurrell et al. 1988; Vaquero et al. 1992; Diepenmaat-Wolters \& Schreuder, 1993; Wolters et al. 1993; Dahiya \& Kapoor, 1994). However, the prediction by in vitro methods of the amounts of macrominerals and trace minerals available for absorption is only relative, because it is not possible to simulate all the important physiological conditions prevailing in the stomach and the small intestine. The method developed by Miller et al. (1981), which permits discrimination between low (LMW)- and high-molecular-weight (HMW) soluble metal complexes, has been used in the present study.

Different authors have postulated that the absorption of some trace minerals, such as $\mathrm{Fe}$ and $\mathrm{Zn}$, is facilitated by LMW-binding ligands (Evans \& Johnson, 1980; Lönnerdal et al. 1980; Layrisse et al. 1984; Taylor et al. 1986; Wapnir \& Stiel, 1986; Politz \& Clydesdale, 1988). However, the chemical composition and the mechanism involved in facilitating absorption are not entirely understood. A better knowledge of the bioavailability of macrominerals and trace minerals, and the factors, such as food components and their digestion products, that may influence this absorption positively or negatively, will contribute to maintaining an optimal mineral balance in animals and man.

The aims of the present study were: (1) to evaluate the effect on $\mathrm{Fe}$ and $\mathrm{Zn}$ absorption of various purified proteins and their digestion products under simulated gastrointestinal conditions, and (2) to study the possible interaction between these two trace minerals.

\section{MATERIALS AND METHODS}

\section{Protein sources and sample preparation}

Three purified proteins were used in the present study: extracted beef and pork proteins and soyabean-protein isolate. The two types of fresh meat were obtained from a local supermarket. Soyabean-protein isolate was provided by a manufacturer.

Meat samples were trimmed of visible fat and ground twice through a $3.175 \mathrm{~mm}$ plate, mixed and maintained at $0^{\circ}$ in plastic bags before protein extraction.

\section{Reagents and materials}

Double-distilled and deionized water (DDW) was used. All glassware and the polyethylene bottles used for the samples were washed and rinsed in distilled water, soaked overnight in 
$10 \mathrm{M}-\mathrm{HNO}_{3}$, and rinsed again with DDW. Pepsin suspension was prepared from pepsin powder (16 g; from porcine stomach mucosa; Sigma Chemical Co., St Louis, MO, USA) which was suspended in $0 \cdot 1 \mathrm{M}-\mathrm{HCl}$ and brought to $100 \mathrm{ml}$ with $0 \cdot 1 \mathrm{M}-\mathrm{HCl}$. Pancreatin-bileextract mixture contained pancreatin ( $4 \mathrm{~g}$; from porcine pancreas; Sigma Chemical Co.) and bile extract ( $25 \mathrm{~g}$; porcine; Sigma Chemical Co.) dispersed in $0.1 \mathrm{M}-\mathrm{NaHCO}_{3}$, the mixture being brought to 11 with $0 \cdot 1 \mathrm{M}-\mathrm{NaHCO}_{3} \cdot \mathrm{FeSO}_{4} \cdot 7 \mathrm{H}_{2} \mathrm{O}$ and $\mathrm{ZnSO}_{4} \cdot 7 \mathrm{H}_{2} \mathrm{O}$ were used as sources of extrinsic $\mathrm{Fe}$ and $\mathrm{Zn}$ respectively. The dialysis tubing comprised segments of dialysis tubing manufactured from natural cellulose, with a molecular weight cut-off of 6000-8000, and a diameter of $32 \mathrm{~mm}$ (Spectra/Por, Spectrum, Houston, TX, USA). Dialysis tubing segments were washed three times with DDW and soaked overnight in $0 \cdot 1 \mathrm{M}-\mathrm{NaHCO}_{3}$. All reagents were of analytical grade and were prepared in DDW.

\section{Meat-protein extraction procedure}

Meat proteins were extracted by placing $50 \mathrm{~g}$ samples of ground meat in a $250 \mathrm{ml}$ Erlenmeyer flask, adding $150 \mathrm{ml}$ of the extraction solution $(90 \mathrm{~g} \mathrm{NaCl} / 1)$ and mixing at moderate speed, with a magnetic stirrer, for $6 \mathrm{~min}$. Extracts were separated from particulate matter by centrifugation at $1475 \mathrm{~g}$ for $10 \mathrm{~min}$. The extracts were decanted and poured through glass-wool filters. Meat samples and extraction solutions and all equipment were equilibrated at the extraction temperature of $7 \cdot 2 \pm 1^{\circ}$ (Gillett et al. 1977). Finally, the extracts of proteins were lyophilized before analysis of the protein and its utilization in in vitro experiments. It has been shown that when the meat used is fresh, uncooked and unfrozen, as in our study, both the extracted proteins obtained by this method and the original meat sources present similar properties in relation to their emulsifying ability (Gillett et al. 1977).

\section{In vitro digestion and separation of the digestion-product fractions}

The in vitro digestion method developed by Miller et al. (1981) was used, with minor modifications. The Miller et al. (1981) method was developed for estimating Fe availability in food mixtures, while in our study we estimated $\mathrm{Fe}$ and $\mathrm{Zn}$ availability from three purified proteins. The extrinsic minerals ( $\mathrm{Fe}$ and/or $\mathrm{Zn}$ ) were added after the digestion process, while in the Miller et al. (1981) method the Fe was added before the digestion process. In the original method the minerals were dialysed during the pancreatin digestion, while in our study the minerals were dialysed after both the digestion process and the separation of the digestion-product fractions. We also used different $\mathrm{pH}$ values, which were necessary to separate both LMW and HMW digestion-product fractions. The different digestionproduct fractions were obtained according to the method of Kane \& Miller (1984). The methods involve a two-stage (pepsin and pancreatin) digestion.

Pepsin digestion. An amount of each product containing the equivalent of 1 or $3 \mathrm{~g}$ protein was placed in a $250 \mathrm{ml}$ plastic bottle and mixed with distilled water. The $\mathrm{pH}$ of the mixture was adjusted to 2.0 using $6 \mathrm{M}-\mathrm{HCl}$ and the pepsin suspension $(2.5 \mathrm{ml})$ was added to the mixtures $(0.361 \mathrm{~g} / 100 \mathrm{~g}$ homogenate). The $\mathrm{pH}$ was re-adjusted to 2.0 and the flask contents were brought to a total weight of $100 \mathrm{~g}$. The bottles were incubated at $37^{\circ}$ for $2 \mathrm{~h}$ in a vigorously-shaking water-bath (rate of oscillation $90 / \mathrm{min}$ ). Throughout the incubation the $\mathrm{pH}$ of the mixtures was maintained at $2 \cdot 0$ (by adding $6 \mathrm{M}-\mathrm{HCl}$ when necessary). Pancreatin digestion which followed pepsin incubation was different for each digestionproduct fraction. Extrinsic $\mathrm{Fe}$ and/or $\mathrm{Zn}$ were not added until after the fractions were prepared.

Pancreatin digestion of the whole fraction. An amount of $\mathrm{NaHCO}_{3}$ equivalent to the titratable acidity measured previously (see p. 730) was placed in each bottle. The bottles were then incubated in a vigorously-shaking water-bath (rate of oscillation $90 / \mathrm{min}$ ) at $37^{\circ}$ 
for $30 \mathrm{~min}$. This was followed by the addition of pancreatin-bile extract $(25 \mathrm{ml} / 100 \mathrm{~g}$ homogenate), and the incubation was continued for a further $2 \mathrm{~h}$. After pancreatin digestion the $\mathrm{pH}$ was adjusted to 2.0 with $6.0 \mathrm{M}-\mathrm{HCl}$.

Pancreatin digestion of the low-and high-molecular-weight fractions. Segments of dialysis tubing containing $200 \mathrm{ml}$ distilled water and an amount of $\mathrm{NaHCO}_{3}$ equivalent to the titratable acidity measured previously were placed in each bottle. The bottles were then incubated in a vigorously-shaking water-bath (rate of oscillation $90 / \mathrm{min}$ ) at $37^{\circ}$ for $30 \mathrm{~min}$. This was followed by the addition of pancreatin-bile extract $(25 \mathrm{ml} / 100 \mathrm{~g}$ homogenate $)$, and the incubation was continued for a further $2 \mathrm{~h}$. At the end of the incubation period the retentate (material outside the dialysis tube) from the in vitro digestion procedure was dialysed against $0.01 \mathrm{M}-\mathrm{HCl}$ for $48 \mathrm{~h}$ at $4^{\circ}$ (to remove the LMW fraction and purify the $\mathrm{HMW}$ fraction). The $\mathrm{HCl}$ was changed every $6 \mathrm{~h}$ (HMW fraction). The dialysis sacs were rinsed with DDW and blotted after removal from the bottles to remove contaminating dialysate. The dialysate from the in vitro digestion procedure was lyophilized and brought to half its original volume with water and sufficient $6.0 \mathrm{M}-\mathrm{HCl}$ to bring the final $\mathrm{pH}$ to $2 \cdot 0$ (LMW fraction). Re-adjustment of the $\mathrm{pH}$ used in the experimental process does not occur in the in vivo situation. However, this re-adjustment of the $\mathrm{pH}$ is a necessary step in the separation method of the digestion-product fractions (method of Kane \& Miller, 1984).

\section{Iron and zinc dialysis experiments}

Samples of the digestion-product fractions $(19.6 \mathrm{ml})$ were transferred to $100 \mathrm{ml}$ plastic bottles. Fe and/or $\mathrm{Zn}$ solutions $(0 \cdot 2 \mathrm{ml})$ were added, giving extrinsic $\mathrm{Fe}$ and/or $\mathrm{Zn}$ concentrations of $10 \mu \mathrm{g} / \mathrm{ml}$. Dialysis tubes containing $25 \mathrm{ml} \mathrm{NaHCO}$ solution of sufficient strength to produce a final $\mathrm{pH}$ of 7.0 were added to each bottle. After gentle shaking (rate of oscillation $100 / \mathrm{min}$ ) at room temperature for $2 \mathrm{~h}$, the dialysis tubes were removed and for each bottle the $\mathrm{pH}$ of retentate and for each dialysis tube the weight of dialysate was measured, rinsed with DDW and blotted. Dialysates were analysed for Fe and $\mathrm{Zn}$.

Blanks containing no added $\mathrm{Fe}$ and $\mathrm{Zn}$ (but otherwise prepared as described previously) were run to determine the contribution of intrinsic $\mathrm{Fe}$ and $\mathrm{Zn}$ to dialysable $\mathrm{Fe}$ and $\mathrm{Zn}$. Blanks (without protein and minerals) containing the components used in the digestion process (enzymes and/or bile extract) were also run throughout the experiment (digestive, dialysis and analytical phases).

Titratable acidity was determined on a $20 \mathrm{~g}$ portion of the pepsin digest to which $5 \mathrm{ml}$ of the pancreatin-bile-extract mixture was added. Titratable acidity was defined as the number of equivalents of $\mathrm{NaOH}$ required to titrate the combined pepsin-digest-pancreatin-bile-extract mixture to $\mathrm{pH} 7 \cdot 0(0 \cdot 5 \mathrm{M}-\mathrm{NaOH}$ was used in the titration).

The dialysability was expressed as a percentage of the total amount of trace mineral (Fe and $\mathrm{Zn}$ ) present in the sample. The percentage was calculated according to the following equation:

$$
\text { dialysability }(\%)=\frac{2 \times \mathrm{D}}{\mathrm{A}} \times 100,
$$

where $\mathrm{D}$ is the amount of mineral dialysed $(\mathrm{mg})$ and $\mathrm{A}$ is the initial amount of mineral present in the sample portion before the dialysis process (mg).

\section{Analytical methods}

Analysis of protein sources, purified proteins, and digestion-product fractions. The Fe and Zn contents were determined by atomic absorption spectrophotometry (model 5000; PerkinElmer Corp., Norwalk, CT, USA). Protein contents were determined by the Kjeldahl method; the $\mathrm{N}$ to protein conversion factor was $6 \cdot 25$. Phytate (myo-inositol hexaphosphate) 
Table 1. Composition of raw meats, soyabean-protein isolate and extracted meat proteins

\begin{tabular}{|c|c|c|c|c|c|}
\hline & \multicolumn{2}{|c|}{ Raw meat } & \multirow{2}{*}{$\begin{array}{c}\text { Isolated } \\
\text { soyabean } \\
\text { protein }\end{array}$} & \multicolumn{2}{|c|}{ Extracted protein } \\
\hline & Beef & Pork & & Beef & Pork \\
\hline Protein $(\mathrm{mg} / \mathrm{g})$ & 233 & 231 & 789 & 12.5 & $10 \cdot 9$ \\
\hline $\mathrm{Fe}(\mu \mathrm{g} / \mathrm{g})$ & $13 \cdot 4$ & $9 \cdot 2$ & $117 \cdot 0$ & $1 \cdot 10$ & 0.65 \\
\hline $\mathrm{Zn}(\mu \mathrm{g} / \mathrm{g})$ & $34 \cdot 0$ & 20.0 & 33.0 & 1.30 & 0.90 \\
\hline
\end{tabular}

Table 2. Contents of phytic acid in the low $(\leqslant 6-8000 \mathrm{Da} ; L M W)$ and high-molecularweight (>6-8000 Da; HMW) fractions from soyabean-protein isolate* at 10 and $30 \mathrm{~g}$ protein $/ \mathrm{kg}$ levels after the digestion and dialysis processest

\begin{tabular}{|c|c|c|}
\hline \multirow[b]{2}{*}{ Protein level $(\mathrm{g} / \mathbf{k g})$} & \multicolumn{2}{|c|}{ Phytic acid (\%) } \\
\hline & HMW fraction & LMW fraction \\
\hline $\begin{array}{l}10 \\
30\end{array}$ & $\begin{array}{l}65 \cdot 1 \\
75 \cdot 7\end{array}$ & $\begin{array}{l}34.9 \\
24 \cdot 3\end{array}$ \\
\hline
\end{tabular}

* Phytic acid (myo-inositol hexaphosphate) $11 \cdot 75 \mathrm{mg} / \mathrm{g}$ protein.

+ For details of procedures, see pp. 728-731.

contents of the soyabean-protein isolate and its digestion-product fractions were determined using the method of Bos et al. (1991), which is a chromatographic method combined with an EDTA treatment of the extracts.

Analysis of dialysates. The $\mathrm{Fe}$ and $\mathrm{Zn}$ contents of the dialysates were determined spectrophotometrically using two reagent kits (catalogue no. 14761 and 14832 respectively; E. Merck, Darmstadt, Germany). The procedures and the reagents for each kit are different, and the complex formed with each mineral ( $\mathrm{Fe}$ or $\mathrm{Zn}$ ) is specific for that mineral; therefore, there should be no interference between the mineral complexes. Fe was determined using the Ferrospectral colour reagent (3-(2-pyridyl)-5,6-bis(4-phenylsulphonic acid)-1,2,4-triazine, disodium salt) and ammonium thioglycolate. In an alkaline solution, $\mathrm{Zn}$ ions react with pyridylazonaphthol to form a chelate complex which is extracted with isobutyl methyl ketone. Absorbance was measured at $565 \mathrm{~nm}$ and $\mathrm{Fe}$ and $\mathrm{Zn}$ were determined by comparison with a standard curve of $0,0 \cdot 1,0.25,0.5,1.0,1.5$ and $2.0 \mathrm{mg} / 1$ using $\mathrm{Fe}\left(\mathrm{NO}_{3}\right)_{3} .9 \mathrm{H}_{2} \mathrm{O}$ in $0.5 \mathrm{M}-\mathrm{HNO}_{3}$ and $\mathrm{Zn}\left(\mathrm{NO}_{3}\right)_{2} .4 \mathrm{H}_{2} \mathrm{O}$ in $0.5 \mathrm{M}-\mathrm{HNO}_{3}$ respectively.

\section{Statistical analysis}

Results are given as means of four or six observations with the standard error of the mean. Statistical evaluation was performed by ANOVA for the type of protein and the presence of $\mathrm{Fe}$ or $\mathrm{Zn}$. Student's $t$ test was conducted for comparisons between groups when a significant variation was demonstrated by ANOVA. A probability level of $P<0.05$ was considered significant.

\section{RESULTS}

The protein, $\mathrm{Fe}$ and $\mathrm{Zn}$ contents of the raw meats used as protein sources and those of the soyabean-protein isolate and extracted meat proteins are given in Table 1. The phytic acid (myo-inositol hexaphosphate) contents of soyabean-protein isolate and its digestionproduct fractions are given in Table 2. 

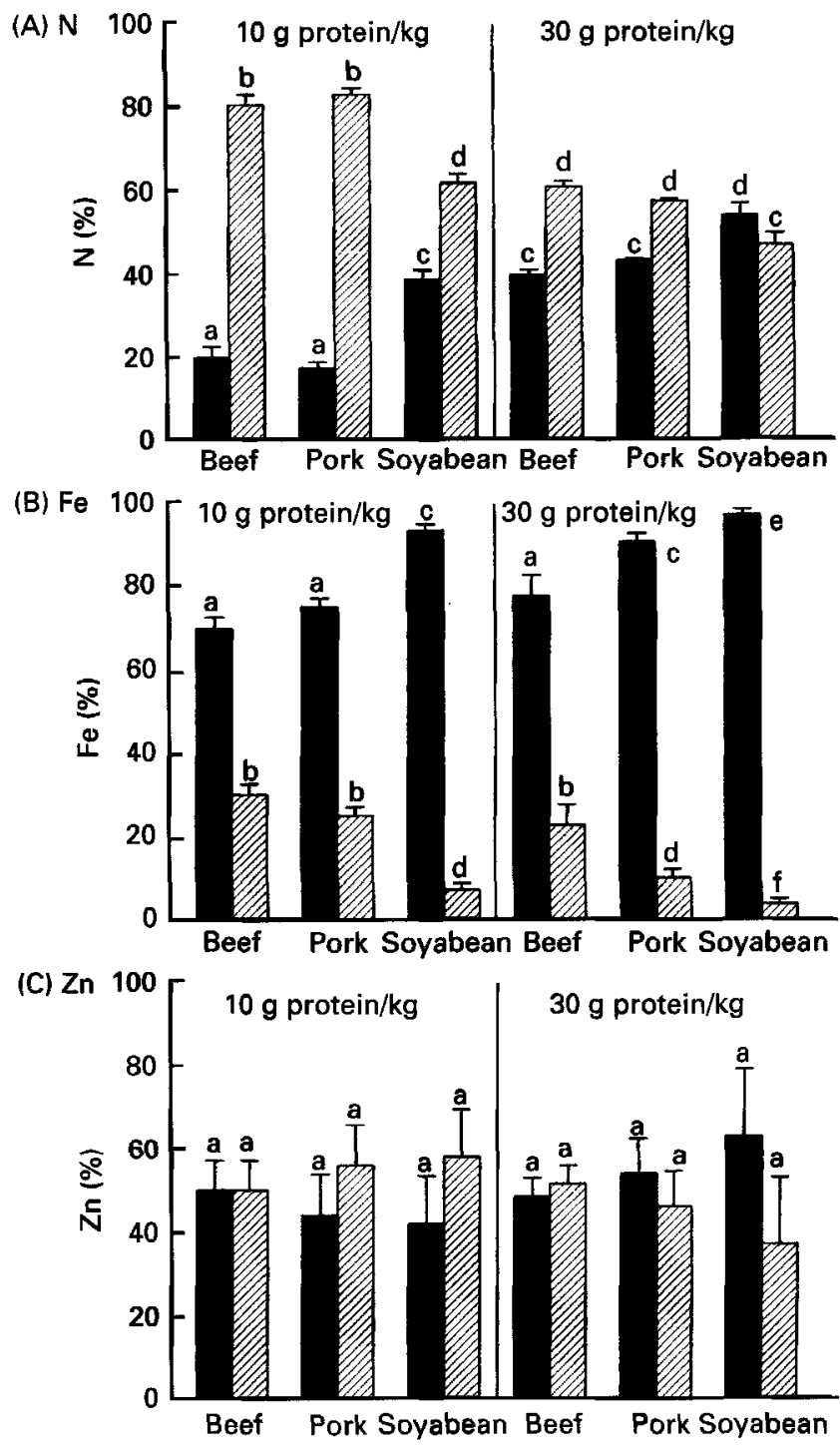

Fig. 1. Percentage distribution of nitrogen (A), iron (B) and zinc (C) from beef, pork and soyabean proteins, at 10 and $30 \mathrm{~g}$ protein $/ \mathrm{kg}$ levels, in low $(\square)$ and high $(\square)$-molecular-weight fractions after the digestion and dialysis processes. Values are means with their standard errors represented by vertical bars for four determinations. $\mathrm{a}, \mathrm{b}, \mathrm{e}, \mathrm{d}, \mathrm{e}, \mathrm{i}$ Means with unlike superscript letters were significantly different (Student's $t$ test): $P<0 \cdot 05$. For details of procedures, see pp. $728-731$.

Fig. 1 shows the percentage distribution of $\mathrm{N}, \mathrm{Fe}$ and $\mathrm{Zn}$ in the digestion-product fractions from in vitro digestion, separated on the basis of molecular weight (LMW fraction $\leqslant 6-8000 \mathrm{Da}$ and HMW fraction $>6-8000 \mathrm{Da}$ ), for the three types of protein at the two levels of protein tested (beef, pork and soyabean proteins; 10 and $30 \mathrm{~g} / \mathrm{kg}$ ). The percentage of hydrolysed protein decreased when the protein level was increased from 10 to $30 \mathrm{~g} / \mathrm{kg}$, independent of protein type used. At both protein levels, soyabean protein showed a lower $\mathrm{N}$ content in the LMW fraction than the other two proteins (Fig. 1 A). When the protein 
Table 3. Percentage dialysability of iron from the beef, pork and soyabean proteins at 10 and $30 \mathrm{~g}$ protein $/ \mathrm{kg}$ levels in presence and absence of added zinc $(10 \mu \mathrm{g} / \mathrm{ml})^{*}$

(Mean values with their standard errors for four determinations)

\begin{tabular}{|c|c|c|c|c|}
\hline \multirow[b]{3}{*}{ Type of protein } & \multicolumn{4}{|c|}{ Dialysability of intrinsic $\mathrm{Fe}(\%)$} \\
\hline & \multicolumn{2}{|c|}{$10 \mathrm{~g}$ protein $/ \mathrm{kg}$} & \multicolumn{2}{|c|}{$30 \mathrm{~g}$ protein $/ \mathrm{kg}$} \\
\hline & Mean & $\mathbf{S E}$ & Mean & SE \\
\hline Beef & $11 \cdot 62^{\mathrm{a}}$ & 1.30 & $14 \cdot 05^{\mathrm{a}}$ & 1.73 \\
\hline Beef $+\mathrm{Zn}(10 \mu \mathrm{g} / \mathrm{ml})$ & $12 \cdot 94^{\mathrm{a}}$ & $1 \cdot 52$ & $14 \cdot 59^{\mathrm{a}}$ & 1.67 \\
\hline Pork & $12 \cdot 97^{\mathrm{a}}$ & 1.89 & $16 \cdot 19^{\mathrm{a}}$ & 2.00 \\
\hline Pork + Zn $(10 \mu \mathrm{g} / \mathrm{ml})$ & $12 \cdot 71^{\mathrm{a}}$ & $2 \cdot 30$ & $17 \cdot 21^{\mathrm{a}}$ & 2.99 \\
\hline Soyabean & $3 \cdot 17^{\mathrm{b}}$ & 0.14 & $2 \cdot 22^{\mathrm{b}}$ & 0.18 \\
\hline Soyabean $+\mathrm{Zn}(10 \mu \mathrm{g} / \mathrm{ml})$ & $0 \cdot 30^{\mathrm{c}}$ & $0-54$ & $0.97^{e}$ & 0.14 \\
\hline
\end{tabular}

a, b,c Means with unlike superscript letters were significantly different (Student's $t$ test): $P<0.005$.

* For details of procedures, see pp. 728-731.

Table 4. Percentage dialysability of zinc from the beef, pork and soyabean proteins at $10 \mathrm{~g}$ protein $/ \mathrm{kg}$ level in presence and absence of added iron $(10 \mu \mathrm{g} / \mathrm{ml})^{*}$

(Mean values with their standard errors for four determinations)

\begin{tabular}{lcc}
\hline & \multicolumn{2}{c}{ Dialysability of intrinsic Zn $(\%)$} \\
\cline { 2 - 3 } Type of protein & Mean & SE \\
\hline Beef & $55 \cdot 42^{\mathrm{a}}$ & $7 \cdot 23$ \\
Beef $+\mathrm{Fe}(10 \mu \mathrm{g} / \mathrm{ml})$ & $54 \cdot 70^{\mathrm{a}}$ & $8 \cdot 30$ \\
Pork & $30 \cdot 13^{\mathrm{b}}$ & $4 \cdot 84$ \\
Pork $+\mathrm{Fe}(10 \mu \mathrm{g} / \mathrm{ml})$ & $31 \cdot 09^{\mathrm{b}}$ & $4 \cdot 25$ \\
Soyabean & $28 \cdot 65^{\mathrm{b}}$ & $2 \cdot 84$ \\
Soyabean $+\mathrm{Fe}(10 \mu \mathrm{g} / \mathrm{ml})$ & $22 \cdot 38^{\mathrm{b}}$ & $2 \cdot 91$ \\
\hline
\end{tabular}

$\mathrm{a}, \mathrm{b}$ Means with unlike superscript letters were significantly different (Student's $t$ test): $P<0.001$.

* For details of procedures, see pp. 728-731.

level was increased, there was also a lower percentage of $\mathrm{Fe}$ and $\mathrm{Zn}$ in the LMW fraction (Fig. 1(B and C)).

The dialysability of Fe from the three purified proteins at the two levels $(10$ and $30 \mathrm{~g} / \mathrm{kg})$ and the effect of added $\mathrm{Zn}(10 \mu \mathrm{g} / \mathrm{ml})$ on the dialysability of intrinsic $\mathrm{Fe}$ are shown in Table 3. Proteins from animal tissues showed the same percentage of dialysable $\mathrm{Fe}$, and these values were significantly higher than that from soyabean protein $(P<0.005)$. There were no differences between the protein levels in the dialysability of intrinsic Fe. The addition of inorganic $\mathrm{Zn}(10 \mu \mathrm{g} / \mathrm{ml})$ had no effect on the dialysability of intrinsic Fe from animal proteins, but it had a significant decreasing effect $(P<0.005)$ on the dialysability of intrinsic $\mathrm{Fe}$ from soyabean protein when it was used at 10 and $30 \mathrm{~g}$ protein $/ \mathrm{kg}$ levels.

Table 4 shows the percentage of dialysable $\mathrm{Zn}$ from the beef, pork and soyabean proteins $(10 \mathrm{~g}$ protein $/ \mathrm{kg})$, in presence and absence of added $\mathrm{Fe}(10 \mu \mathrm{g} / \mathrm{ml})$. The dialysability of $\mathrm{Zn}$ from beef protein was significantly $(P<0.005)$ higher than that from the other proteins 


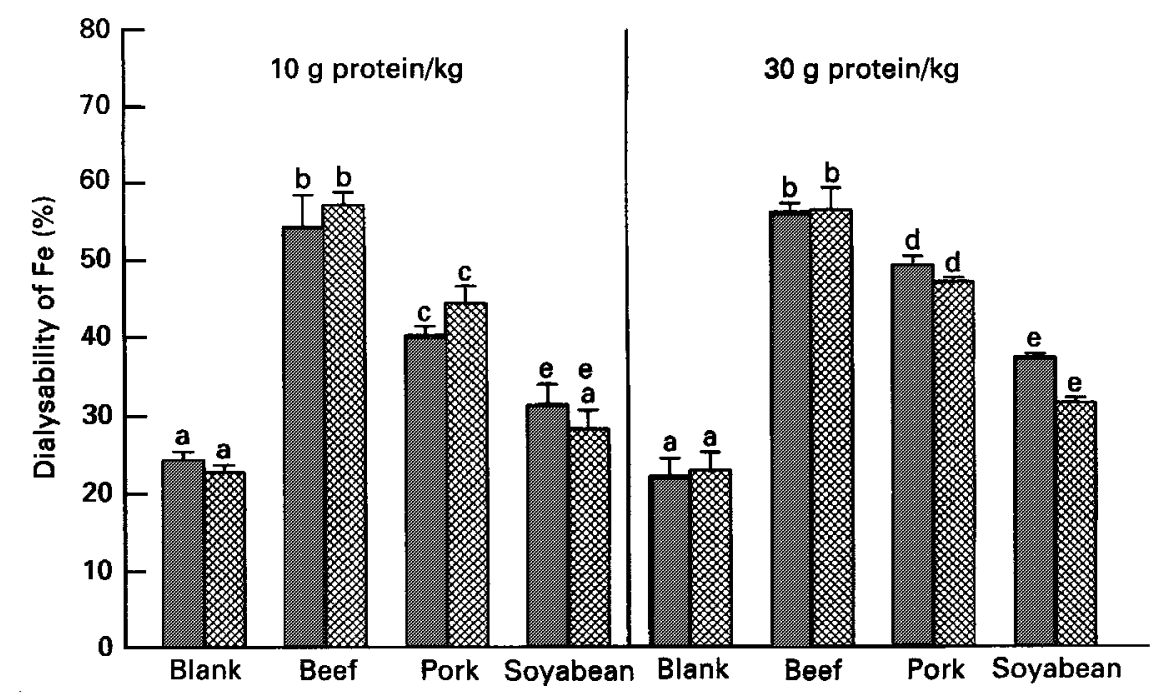

Fig. 2. The effect of the type and level of protein ( 10 and $30 \mathrm{~g} / \mathrm{kg})$ on the dialysability of extrinsic iron $(10 \mu \mathrm{g} / \mathrm{ml})$, in presence (图) and absence ( $)$ of zinc $\left(10 \mu \mathrm{g} / \mathrm{ml}\right.$ ), added as $\mathrm{ZnSO}_{4}$ after in vitro digestion (combined digestionproduct fractions). Values are means with their standard errors represented by vertical bars for four

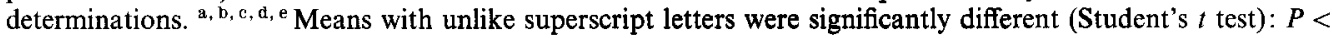
0.05 . For details of procedures, see pp. 728-731.

studied. The dialysability of intrinsic $\mathrm{Zn}$ from soyabean isolate was the lowest of the three proteins tested, but it did not differ significantly from that from pork protein. The addition of Fe had no effect on the dialysability of intrinsic $\mathrm{Zn}$.

Fig. 2 shows the effect of the type and level of protein on the percentage dialysability of extrinsic $\mathrm{Fe}$, added as $\mathrm{Fe}^{2+}(10 \mu \mathrm{g} / \mathrm{ml})$. The three proteins had a significant enhancing effect (beef and pork proteins $P<0.001$, soyabean protein $P<0.05$ ) on the dialysability of extrinsic Fe in relation to the blank (only the enzymes and bile extract were present during digestion). The addition or inorganic $\mathrm{Zn}$ had no effect on the dialysability of extrinsic Fe. As can be seen also from Fig. 2, when the protein level was increased, the percentage dialysability of extrinsic Fe tended to increase, but was only significant $(P<0.002)$ in the case of pork protein.

The effects on the dialysability of extrinsic Fe of the digestion-product fractions from the three proteins at each of the two levels $(10$ and $30 \mathrm{~g} / \mathrm{kg}$ ) are shown in Fig. 3. The LMW fractions of the different types and levels of proteins had no effect on the dialysability of extrinsic Fe, while for the HMW fraction the effect was significantly different $(P<0.001)$ between both the types and the levels of protein used.

Fig. 4 shows the effects of the type of protein and its digestion-product fractions on the dialysability of extrinsic $\mathrm{Zn}$, added as $\mathrm{ZnSO}_{4}$ at $10 \mu \mathrm{g} / \mathrm{ml}$, in presence and absence of added $\mathrm{Fe}(10 \mu \mathrm{g} / \mathrm{ml})$. There were no differences in the dialysability of extrinsic $\mathrm{Zn}$ between the proteins. The addition of inorganic Fe had no effect on the dialysability of extrinsic $\mathrm{Zn}$. As can be seen from Fig. 4, in all cases the percentage dialysability of extrinsic $\mathrm{Zn}$ in the presence of the LMW fraction was significantly higher than that with the HMW fraction $(P<0.001)$.

Finally, Fig. 5 shows the effects on the dialysability of extrinsic $\mathrm{Fe}$ and $\mathrm{Zn}$ of the different components used in the in vitro digestion process (enzymes, pepsin and pancreatin, and bile extract), as well as those of their digestion-product fractions. Dialysability for Fe was very high for the enzymes and the LMW fractions, intermediate for the combined fractions (all 


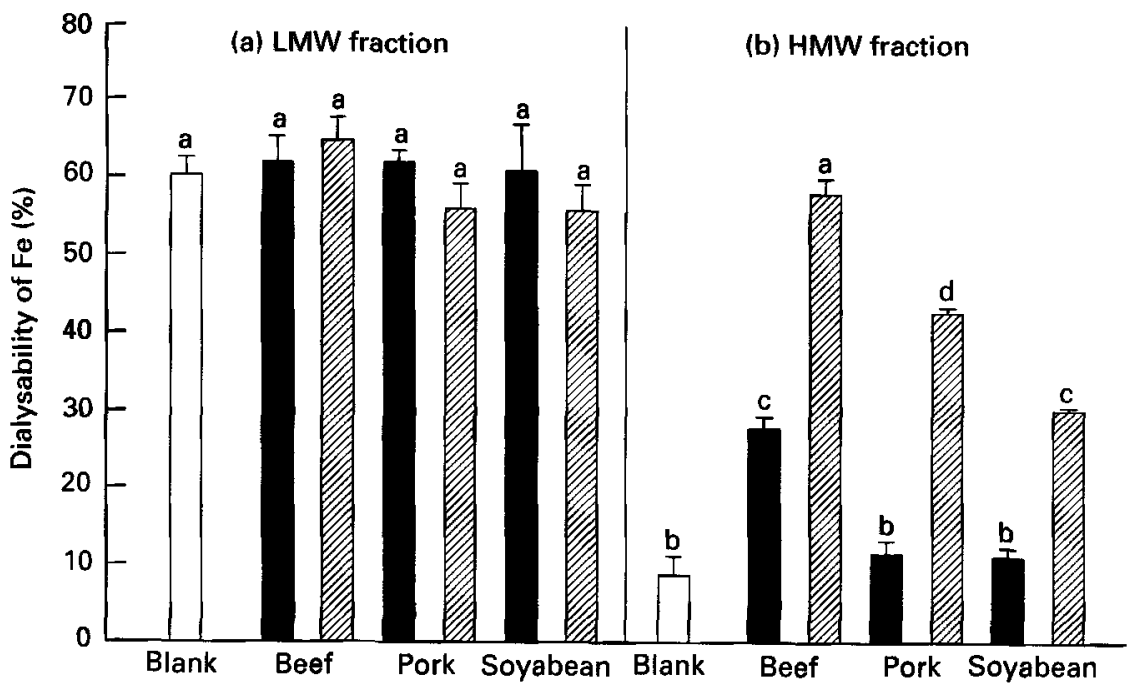

Fig. 3. The effect of the type and level of protein $(10(\square)$ and $30(\square) \mathrm{g} / \mathrm{kg})$ after in vitro digestion on the dialysability of extrinsic iron $(10 \mu \mathrm{g} / \mathrm{ml})$ added as $\mathrm{FeSO}_{4}$. (a) Low ( $\left.\leqslant 6-8000 \mathrm{Da} ; \mathrm{LMW}\right)$ and (b) high (> 6-8000 Da; HMW)-molecular-weight digestion-product fractions. ( $\square$ ), Blank (only the enzymes, bile extract and extrinsic $\mathrm{Fe}$ ). Values are means with their standard errors represented by vertical bars for six determinations a. b. e, d Means with unlike superscript letters were significantly different (Student's $t$ test) $: P<0 \cdot 001$. For details of procedures, see pp. 728-731.

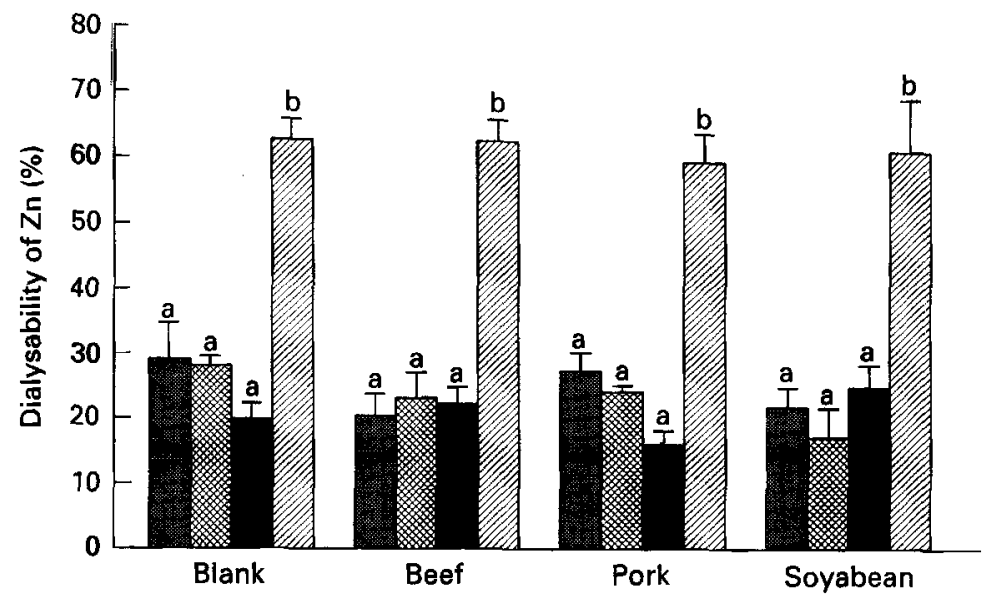

Fig. 4. The effect of the type of protein $10 \mathrm{~g} / \mathrm{kg}$ level after in vitro digestion on the dialysability of extrinsic zinc $(10 \mu \mathrm{g} / \mathrm{ml})$. (雨) Combined digestion-product fractions; $(\mathrm{x})$, combined digestion-product fractions in presence of iron $(10 \mu \mathrm{g} / \mathrm{ml})$, added as $\mathrm{FeSO}_{4} ;(\square)$ high-molecular-weight fraction (> 6-8000 Da); ( $\left.\square\right)$, low-molecular-weight fraction $(\leqslant 6-8000 \mathrm{Da})$. Values are means with their standard errors represented by vertical bars for four or six determinations. ${ }^{a, b}$ Means with unlike superscript letters were significantly different (Student's $t$ test): $P<0 \cdot 001$. For details of procedures, see pp. 728-731.

components together), and very low for bile extract and HMW fractions $(P<0.005)$. Dialysabilities for $\mathrm{Zn}$ were the same from the combined and HMW fractions and both values were significantly lower than that from the enzymes, the bile extract and the LMW fraction $(P<0.005)$. Bile salts had a strongly inhibiting effect on the dialysability of $\mathrm{Fe}$ $(P<0.005)$, but not that of $\mathrm{Zn}$. 


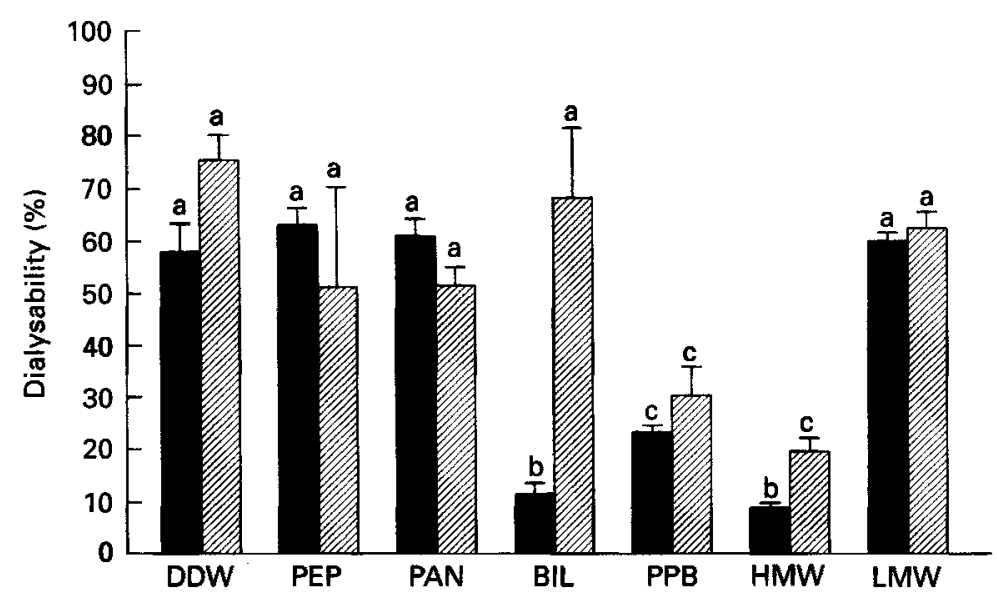

Fig. 5. Effect of the different components used in the digestion process (blank) on the dialysability of extrinsic iron ( $)$ and zinc ( $\square)$. DDW, double-distilled and deionized water; PEP, pepsin; PAN, pancreatin; BIL, bile extract; PPB, all components, LMW, HMW, low ( $\leqslant 6-8000$ Da)- and high ( $>6-8000 \mathrm{Da}$ )-molecular-weight fractions from all components. Values are means with their standard errors represented by vertical bars for four determinations. $^{\mathrm{a}, \mathrm{b}, \mathrm{c}}$ Means with unlike superscript letters were significantly different (Student's $t$ test) $: P<0.005$.

\section{DISCUSSION \\ Proteins and the availability of intrinsic iron and zinc}

Studies reported in the literature have suggested that the absorption of some trace minerals can be related to the affinity that some products which are formed and/or released during the protein digestion process have for these minerals (Layrisse et al. 1984; Berner \& Miller, 1985; Politz \& Clydesdale, 1988; Slatkavitz \& Clydesdale, 1988; Hurrell et al. 1989; Wapnir, 1989). The results from the present study on in vitro availability support these observations for $\mathrm{Fe}$, but not for $\mathrm{Zn}$.

After the in vitro digestion and dialysis processes, a lower percentage of $\mathrm{N}, \mathrm{Fe}$ and $\mathrm{Zn}$ was found in the LMW fractions where the protein level was increased from 10 to $30 \mathrm{~g} / \mathrm{kg}$. This difference in distribution between LMW and HMW fractions was independent of the type of protein used. Because the concentration of enzymes and the duration of the digestion processes in these experiments were the same for both protein levels, we suggest that these events are related to a lower degree of protein hydrolysis in the experiment with the highest protein level. Fig. 1 shows that most of the Fe is found in the HMW fraction. It is known from the literature that HMW peptides can bind, or include, macrominerals and trace minerals (Politz \& Clydesdale, 1988; Slatkavitz \& Clydesdale, 1988; Wapnir, 1989). Our results are consistent with those of Hurrell et al. (1989), who conducted a study to compare the effect of casein and whey proteins on the dialysability of Fe under simulated gastrointestinal conditions. They observed that when intact milk-protein products were replaced by enzyme-hydrolysed preparations, the percentage of dialysable Fe increased markedly and in proportion to the extent of hydrolysis.

Fe and $\mathrm{Zn}$ distribution in the LMW and HMW fractions differed markedly. The highest percentage intrinsic Fe was always found in HMW fractions, independent of the type and level of protein studied. In the case of $\mathrm{Zn}$, it was found at similar percentages in the LMW and HMW fractions. The difference in behaviour of the trace minerals can partly explain the different in vitro absorption observed in Tables 3 and 4. The dialysability of $\mathrm{Zn}$ was always higher than that of $\mathrm{Fe}(22-55 \%$ for intrinsic $\mathrm{Zn}$ and $0 \cdot 3-13 \%$ for intrinsic $\mathrm{Fe}$, depending on the protein type). 
At both protein levels studied the lowest level of N in the LMW fractions was found in the soyabean-protein-isolate experiments. Our data also showed that the in vitro availability of $\mathrm{Fe}$ from soyabean-protein isolate was lower than that from animal proteins. This could be due to the presence of phytate in this protein. Our data on the distribution of phytic acid in the LMW- and HMW-peptide fractions also support this observation; it was higher in the HMW fraction at $30 \mathrm{~g} / \mathrm{kg}$ than that at $10 \mathrm{~g}$ protein $/ \mathrm{kg}$. It has been reported that phytic acid can be found in the form of complexes with essential minerals and/or proteins (Erdman, 1979; Cheryan, 1980). Many of these complexes are insoluble and are not bioavailable under normal physiological conditions (deRham \& Jost, 1979; Nosworthy \& Caldwell, 1988). In addition, proteins bound to phytate are less subject to attack by proteolytic enzymes than the free proteins (Rodriguez et al. 1985; Champagne \& Phillippy, 1989).

Conversely, the dialysability of intrinsic $\mathrm{Zn}$ from pork and soyabean proteins were similar, while in the beef-protein experiment it was significantly higher. These findings suggest that phytic acid did not have a negative effect on the dialysability of intrinsic $\mathrm{Zn}$ from soyabean protein. Apparently, the higher availability of $\mathrm{Zn}$ from beef protein also suggests the presence of an enhancing factor(s) in this meat.

\section{Interactions between iron and zinc}

As mentioned previously, competitive interactions occur between $\mathrm{Zn}$ and $\mathrm{Fe}$ at the level of absorption in human subjects and experimental animals. It was demonstrated that $\mathrm{Zn}$ inhibits Fe absorption, and vice versa, when the minerals are administered together (Solomons \& Jacob, 1981; Solomons et al. 1983; Sandström et al. 1985; Fairweather-Tait \& Southon, 1989). These interactions may be associated with ligands (LMW substances that bind inorganic ions) and/or their common transport sites in the bowel wall. In an in vitro study, as has been shown here, it is only possible to explore the first interaction (with ligands). This is not the only limitation that the in vitro method presents; as mentioned previously, the in vitro methods are only an approximation of the in vivo situation. In vitro methods cannot be considered, therefore, as an excellent alternative to in vivo techniques. However, because animal and human studies are expensive, time-consuming and difficult to control, it appears that there could be some advantage in screening different foods and their constituents for mineral availability using an in vitro technique.

At the concentrations used in the present study $(10 \mu \mathrm{g} / \mathrm{ml}$, for both trace minerals $)$, there was only an interaction between inorganic $\mathrm{Zn}$ and non-haem-Fe. The addition of inorganic $\mathrm{Zn}$ reduced the dialysability of $\mathrm{Fe}$ from soyabean protein (non-haem-Fe), while it did not affect the dialysability of Fe from beef and pork proteins (about $40 \%$ haem-Fe). These results are probably related to the presence of two chemical forms of Fe in animal and vegetable foods. It is well known that the bioavailability of non-haem-Fe is influenced by other dietary factors, while that of haem-Fe is relatively unaffected (Martínez-Torres \& Layrisse, 1971 ; Sayers et al. 1973; Hallberg, 1981; Gillooly et al. 1984; Monsen, 1988). Our results are in agreement with those of Solomons \& Jacob (1981), who found a competitive interaction between non-haem-Fe and $\mathrm{Zn}$, but no interaction in the case of haem-Fe. We found no interaction between the minerals when they were both used in the inorganic form. The findings described here do not exclude interactions between inorganic forms of $\mathrm{Fe}$ and $\mathrm{Zn}$ at other molar ratios, as observed by other authors (Meadows et al. 1983; Valberg et al. 1984; Fairweather-Tait \& Southon, 1989).

\section{Proteins and the availability of extrinsic iron and zinc}

Results for the combined fractions (all components of the in vitro digestion process) show that the effect on the dialysability of extrinsic Fe differed from protein-to-protein. In all 
cases, the presence of protein increased the dialysability of extrinsic Fe in relation to the blank (where only the enzymes, bile extract and extrinsic Fe were present). This enhancing effect was greater for pork and beef proteins than for soyabean protein. One possible explanation for these findings is that the factor(s) which enhance the availability of extrinsic $\mathrm{Fe}$ is (are) present in higher concentrations and/or may have a greater effect in meat proteins than that in soyabean protein. An alternative explanation for these findings is a possible negative effect of phytic acid in soyabean protein. Conversely, the dialysability of extrinsic $\mathrm{Zn}$ was not affected by the presence or absence of protein.

In order to explain the findings of our in vitro study, for each protein we separated two fractions, on the basis of molecular weight, during the digestion process and studied their separate effects on the dialysabilities of Fe and $\mathrm{Zn}$. Results for LMW and HMW fractions showed different data for extrinsic $\mathrm{Fe}$ and $\mathrm{Zn}$ dialysability.

Our findings on the effect of both the LMW and HMW fractions on the dialysability of $\mathrm{Zn}$ suggest that the type of protein had no effect on its absorption. The data also demonstrated that the dialysability of $\mathrm{Zn}$, added as $\mathrm{ZnSO}_{4}$, was the same with soyabeanprotein isolate as that with animal proteins. This finding is consistent with those of other in vivo studies (Greger et al. 1978; Van Stratum \& Rudrum, 1979; Bodwell, 1983; Miles et al. 1987).

On the other hand, in the case of Fe the behaviour of the proteins tested was different. Results shown in Fig. 3 suggest that the LMW fractions do not account for the enhancing effect of proteins observed in Fig. 2, and that only HMW fractions play an important role in this effect. However, the percentage dialysability of extrinsic Fe was higher when both the LMW and HMW fractions were present than when the HMW fractions alone were present. Similar observations have been reported also by Slatkavitz \& Clydesdale (1988). In addition, the effect of the HMW fraction on the dialysability of Fe depended on its concentration; when the concentration of the HMW fraction was higher, the effect on availability was higher.

We postulate that both the LMW and HMW digestion-product fractions are of importance in the enhancing effect of a protein on the availability of extrinsic Fe, but that their effect is associated with the presence of one or more factors which have an inhibitory effect. This view is supported by the data from Fig. 5. When we studied the individual effect of each of the components used in the in vitro digestion process (blank experiments) on the dialysability of extrinsic $\mathrm{Fe}$, we found that one of these components (bile extract) had a strong inhibitory effect on the dialysability of $\mathrm{Fe}$. These findings also suggest that after the digestion and dialysis processes the negative effect from the bile extract was only present in the HMW fraction. The absence of a negative effect associated with bile salts and, in the case of the soyabean protein the low content of phytic acid, could explain why free amino acids and/or small peptides (released during the digestion of beef, pork and soyabean proteins (LMW fractions)) did not appear to affect the dialysability of extrinsic Fe in our experiments.

The mechanism by which HMW fractions solubilize Fe and facilitate its transport across the dialysis membrane is not clear, it is possible that these HMW digestion products from proteins can, in some way, prevent the binding of $\mathrm{Fe}$ by bile salts. The formation of insoluble trace mineral-bile salt complexes at $\mathrm{pH} 7$ has been suggested by Champagne (1989).

In summary, although our in vitro results cannot be directly applicable to the 'real diet', our findings show the possible effects of dietary protein on the absorption of $\mathrm{Fe}$ and $\mathrm{Zn}$. The results of the present study suggest that the effect of a protein on the absorption of Fe in vitro could not be attributed only to the presence of free amino acids and/or small peptides released during the digestion process. They also suggest that the undigested or 
partially-digested HMW fraction of hydrolysed proteins plays a fundamental role in the absorption of Fe. It appears from our findings that the net effect of a protein on the availability of extrinsic Fe is a combination of the effects of the formation of Fe complexes and/or binding of Fe by both the LMW and HMW digestion-product fractions. The affinity of these compounds for Fe could determine the dialysability of $\mathrm{Fe}$ and, hence, its bioavailability for absorption.

This study was supported by the European Communities under the Comett Programme (Bc/94) and through of the AUEF Fundación Universidad Empresa de Murcia (Spain).

\section{REFERENCES}

Berner, L. A. \& Miller, D. D. (1985). Effects of dietary proteins on iron bioavailability - a review. Food Chemistry 47, 47-69.

Bodwell, C. E. (1983). Effects of soy protein on iron and zinc utilization in humans. Cereal Foods World 28 , 342-348.

Bos, K. D., Verbeek, C., Van Eeden, C. H. P., Slump, P. \& Wolters, M. G. E. (1991). Improved determination of phytate by ion-exchange chromatography. Journal of Agricultural and Food Chemistry 39, 1770-1772.

Champagne, E. T. (1989). Low gastric hydrochloric acid secretion and mineral bioavailability. Advances in Experimental Medicine and Biology 249, 173-184.

Champagne, E. T. \& Phillippy, B. Q. (1989). Effects of $\mathrm{pH}$ on calcium, zinc and phytate solubilities and complexes following in vitro digestion of soy protein isolate. Journal of Food Science 54, 587-592.

Cheryan, M. (1980). Phytic acid interactions in food systems. CRC Critical Reviews in Food Science and Nutrition 13, 297-335.

Churella, H. R. \& Vivian, V. M. (1989). Effect of phytic acid level in soy protein based infant formulas on mineral availability in the rat. Journal of Agricultural and Food Chemistry 37, 1352-1357.

Cook, J. D., Morck, T. A. \& Lynch, S. R. (1981). The inhibitory effect of soy products on nonheme iron absorption in man. American Journal of Clinical Nutrition 34, 2622-2629.

Cossack, Z. T. \& Prasad, A. S. (1983). Effect of protein source on the bioavailability of zinc in human subjects. Nutrition Research 3, 23-31.

Dahiya, S. \& Kapoor, A. C. (1994). In vitro and in vivo availability of iron from home processed supplementary foods. Journal of Food Science and Technology 31, 122-125.

deRham, O. \& Jost, T. (1979). Phytate-protein interactions in soyabean extracts and low-phytate soy protein products. Journal of Food Science 44, 596-600.

Diepenmaat-Wolters, M. G. E. (1992). Prediction of the bioavailability of minerals and trace elements. PhD Thesis, Wageningen Agricultural University.

Diepenmaat-Wolters, M. G. E. \& Schreuder, H. A. W. (1993). A continuous in vitro method for estimation of the bioavailability of minerals and trace elements in foods. In Nutritional, Chemical and Food Processing Implication of Nutrient Availability, pp. $43-47$ [U. Schlemmer, editor]. Karlsruhe, Germany: B. F. E. Karlsruhe.

Erdman, J. W. Jr (1979). Oilseed phytates: nutritional implications. Journal of the American Oil Chemists' Society 56, 736-741.

Evans, G. W. \& Johnson, P. E. (1980). Characterization and quantitation of a zinc-binding ligand in human milk. Pediatrics Research 14, 876-880.

Fairweather-Tait, S. J. \& Southon, S. (1989). Studies of iron:zinc interactions in adult rats and the effect of iron fortification of two commercial infant weaning products on iron and zinc status of weanling rats. Journal of Nutrition 119, 599606.

Forbes, R. M., Weingartner, K. E., Parker, H. M., Bell, R. R. \& Erdman, J. W. (1979). Bioavailability to rats of zinc, magnesium and calcium in casein-, egg- and soy protein-containing diets. Journal of Nutrition 109 , $1652-1660$.

Gillett, T. A., Meiburg, D. E., Brown, C. L. \& Simon, S. (1977). Parameters affecting meat protein extraction and interpretation of model system data for meat emulsion formation. Journal of Food Science 42, 1606-1610.

Gillooly, M., Torrance, J. D., Bothwell, T. H., MacPhail, A. P., Mills, W. \& Mayet, F. (1984). The relative effect of ascorbic acid on iron absorption from soy-based and milk-based infant formulas. American Journal of Clinical Nutrition 40, 522-527.

Gordon, D. T. \& Godber, J. S. (1989). The enhancement of nonheme iron bioavailability by beef protein in the rat. Journal of Nutrition 119, 446-452.

Greger, J. L. (1989). Effect of dietary protein and minerals on calcium and zinc utilization. CRC Critical Reviews in Food Science and Nutrition 28, 249-271.

Greger, J. L., Abernathy, R. P. \& Bennett, O. A. (1978). Zinc and nitrogen balance in adolescent females fed varying levels of zinc and soy protein. American Journal of Clinical Nutrition 31, 112-116. 
Hallberg, L. (1981). Bioavailability of dietary iron in man. Annual Review of Nutrition 1, $123-147$.

Hallberg, L. (1987). Wheat fiber, phytates and iron absorption. Scandinavian Journal of Gastroenterology 22 , 73-79.

Hurrell, R. F., Lynch, S. R., Trinidad, T. P., Dassenko, S. A. \& Cook, J. D. (1988). Iron absorption in humans: bovine serum albumin compared with beef muscle and egg white. American Journal of Clinical Nutrition 47, $102-107$.

Hurrell, R. F., Lynch, S. R., Trinidad, T. P., Dassenko, S. A. \& Cook, J. D. (1989). Iron absorption in humans as influenced by bovine milk proteins. American Journal of Clinical Nutrition 49, 546-552.

Kane, A. P. \& Miller, D. D. (1984). In vitro estimation of the effects of selected proteins on iron bioavailability. American Journal of Clinical Nutrition 39, 393-401.

Layrisse, M., Martínez-Torres, C., Leets, I., Taylor, P. \& Ramírez, J. (1984). Effect of histidine, cysteine, glutathione or beef on iron absorption in humans. Journal of Nutrition 114, 217-223.

Lönnerdal, B., Stanislowski, A. G. \& Hurley, L. S. (1980). Isolation of a low molecular weight zinc binding ligand from human milk. Journal of Inorganic Biochemistry 12, 71-78.

Martinez-Torres, C. \& Layrisse, M. (1971). Iron absorption from veal muscle. American Journal of Clinical Nutrition 24, 521-540.

Meadows, N. J., Grainger, S. L., Ruse, W., Keeling, P. W. N. \& Thompson, R. P. H. (1983). Oral iron and bioavailability of zinc. British Medical Journal 287, 1013-1014.

Miles, C. W., Bodwell, C. E., Morris, E., Ziyad, J. A., Prather, E. S., Mertz, W. \& Canary, J. J. (1987). Long-term consumption of beef extended with soy protein by men, women and children: I. Study design, nutrient intakes, and serum zinc levels. Plant Foods for Human Nutrition 37, 341-359.

Miller, D. D., Schricker, B. R., Rasmussen, R. R. \& Van Campen, D. (1981). An in vitro method for estimation of iron availability from meals. American Journal of Clinical Nutrition 34, 2248-2256.

Mills, C. F. (1985). Dietary interactions involving the trace elements. Annual Review of Nutrition 5, $173-193$.

Monsen, E. R. (1988). Protein-iron interactions: influences on absorption, metabolism, and status. In Nutrient Interactions, pp. 149-162 [C. E. Bodwell and J. W. Erdman Jr, editors]. New York: Marcel Dekker.

Narasinga Rao, B. S. \& Prabhavathi, T. (1978). An in vitro method for predicting the bioavailability of iron from foods. American Journal of Clinical Nutrition 31, 169-175.

Nosworthy, N. \& Caldwell, R. A. (1988). The interaction of zinc (II) and phytic acid with soya bean glycinin. Journal of the Science of Food and Agriculture 44, 143-150.

Politz, M. L. \& Clydesdale, F. M. (1988). Effect of enzymatic digestion, pH and molecular weight on the iron solubilizing properties of chicken muscle. Journal of Food Science 53, 1081-1090.

Rodríguez, C. J., Morr, C. V. \& Kunkel, M. E. (1985). Effect of partial phytate removal and heat upon iron bioavailability from soy protein-based diets. Journal of Food Science 50, 1072-1075.

Rosenberg, I. H. \& Solomons, N. W. (1982). Biological availability of minerals and trace elements: a nutritional overview. American Journal of Clinical Nutrition 35, 781-782.

Sandström, B. (1988). Factors influencing the uptake of trace elements from the digestive tract. Proceedings of the Nutrition Society 47, 161-167.

Sandström, B., Davidsson, L., Cederblad, A. \& Lönnerdal, B. (1985). Oral iron, dietary ligands and zinc absorption. Journal of Nutrition 115, 411-414.

Sayers, M. H., Linch, S. R., Jacobs, P., Charlton, R. W., Bothwell, T. H., Walter, R. B. \& Mayet, F. (1973). The effects of ascorbic acid supplementation on the absorption of iron in maize, wheat and soya. British Journal of Haematology 24, 209-218.

Schricker, B. R., Miller, D. D. \& Van Campen, D. (1982). In vitro estimation of iron availability in meals containing soy products. Journal of Nutrition 112, 1696-1705.

Slatkavitz, C. A. \& Clydesdale, F. M. (1988). Solubility of inorganic iron as affected by proteolytic digestion. American Journal of Clinical Nutrition 47, 487-495.

Snedeker, S. M. \& Greger, J. L. (1983). Metabolism of zinc, copper and iron as affected by dietary protein, cysteine and histidine. Journal of Nutrition 113, 644-652.

Solomons, N. W. (1982). Factors affecting the bioavailability of zinc. Journal of the American Dietetic Association 80, $115-121$.

Solomons, N. W. \& Jacob, R. A. (1981). Studies on the bioavailability of zinc in humans: effects of heme and nonheme iron on the absorption of zinc. American Journal of Clinical Nutrition 34, 475-482.

Solomons, N. W., Pineda, O., Viteri, F. \& Sandstead, H. H. (1983). Studies on the bioavailability of zinc in humans: mechanism of intestinal interaction of nonheme iron and zinc. Journal of Nutrition 113, 337-349.

Taylor, P. G., Martínez-Torres, M. A., Romano, E. L. \& Layrisse, M. (1986). The effect of cysteine-containing peptides released during meat digestion on iron absorption in humans. American Journal of Clinical Nutrition 43, 68-71.

Thompson, D. B. \& Erdman, J. W. (1984). The effect of soy protein isolate in the diet on retention by the rat of iron from radio-labeled test meals. Journal of Nutrition 114, 307-311.

Valberg, L. S., Flanagan, P. R. \& Chamberlain, M. J. (1984). Effects of iron, tin, and copper on zinc absorption in humans. American Journal of Clinical Nutrition 40, 536-541.

Van Dokkum, W., Wesstra, A., Luyken, R. \& Hermus, R. J. J. (1986). The effects of a high-animal- and highvegetable-protein diet on mineral balance and bowel function of young men. British Journal of Nutrition $\mathbf{5 6}$, $341-348$. 
Van Stratum, P. G. \& Rudrum, M. (1979). Effects of consumption of processed soy proteins on minerals and digestion in man. Journal of the American Oil Chemists' Society 56, 130-134.

Vaquero, M. P., Van Dokkum, W., Bos, K. D. \& Wolters, M. G. E. (1992). In vitro availability of calcium, magnesium, iron, copper, and zinc from white or brown bread separately or in combination with other foods. Revista Española de Ciencia y Tecnología de Alimentos 32, 47-57.

Wapnir, R. A. (1989). Protein digestion and the absorption of mineral elements. Advances in Experimental Medicine and Biology 249, 95-115.

Wapnir, R. A. \& Devas, D. (1995). Copper deficiency: interaction with high-fructose and high-fat diets in rats. American Journal of Clinical Nutrition 61, 105-110.

Wapnir, R. A. \& Stiel, L. (1986). Zinc intestinal absorption in rats: specificity of amino acids as ligands. Journal of Nutrition 116, 2171-2179.

Wolters, M. G. E., Diepenmaat, H. B., Hermus, R. J. J. \& Voragen, A. G. J. (1993). Relation between in vitro availability of minerals and food composition: a mathematical model. Journal of Food Science 58, 1349-1355. 